\title{
Correction to: "Please Teach Students that Sex is a Healthy Part of Growing Up": Australian Students' Desires for Relationships and Sexuality Education
}

\author{
Andrea Waling $^{1} \cdot$ Paulina Ezer $^{1} \cdot$ Lucille Kerr $^{1} \cdot$ Roz Bellamy $^{1} \cdot$ Jayne Lucke $^{1} \cdot$ Christopher Fisher $^{1}$
}

Published online: 28 May 2021

○) Springer Science+Business Media, LLC, part of Springer Nature 2021

\section{Correction to: Sexuality Research and Social Policy https://doi.org/10.1007/s13178-020-00516-z}

The original version of this article unfortunately contained an incorrect order of the authors. The author group is now corrected.

Publisher's Note Springer Nature remains neutral with regard to jurisdictional claims in published maps and institutional affiliations.

The original article can be found online at https://doi.org/10.1007/ s13178-020-00516-z.

Christopher Fisher c.fisher2@latrobe.edu.au

1 Australian Research Centre in Sex, Health \& Society, School of Psychology and Public Health College of Science, Health and Engineering, La Trobe University, La Trobe, VIC,

Bundoora, Australia 